\title{
Geo-economic Character of GVC in the Global Reproductive Process System
}

\author{
Anar Rzayev \\ Azerbaycan State University of Economics \\ Azerbaijan, Baku AZ 1001 \\ a.rzayev@list.ru \\ Farid Dilavarov \\ Sumgayit State University \\ Azerbaijan, Sumgayit, AZ5008 \\ farid90.08@mail.ru
}

\author{
Ganira Ibrahimova \\ Siegen University \\ Germany, Siegen D - 57072 \\ ibr.ganira@gmail.com
}

\begin{abstract}
Today there are at least two ways to analyze the world economy: the first one is to look at it through the prism of growth and institutional changes in developed and developing economies, within the international division of the production process. The second way is to look at it through the prism of Global Value Chains (GVC), which are crossing national borders and form a complex network goods, services, capital and technology flows. Both approaches are important and complementing each other. Each country, through its participation in international trade system and transnationalization of capital, is directly involved in the global reproduction process. However, the degree of effectiveness is determined by a country's involvement in the GVC level, as this system reflects the amount of value added, created in a country. It is this volume, that determines the quality of economic growth and generates the national wealth of a country. The aim of our study is to determine the importance of a country in GVC, in terms of its' geo-economic component and the quality of value added dynamics. The paper deals with the geo-economic aspects of the global value chains. Based on the analysis of value added indicators and final consumption by sectors of the Azerbaijani economy, the specifics of the country's participation in GVC have been determined.
\end{abstract}

Keywords-GVC, TiVA, Production Potential, Reproduction Process, Coating Coefficient, Food and Chemical Industry. Regression analysis, intermediate consumption.

\section{INTRODUCTION}

The analysis shows that in the period between 1995-2009 the country's involvement in GVC was in average 5-10\%; in the period between 2010-2017 the level of integrated activities was $58.1 \%$, with a particularly high contribution (76.4\%) due to a 4.2 percentage point increase in GVC's share in the high technology sector. Approximately 45\%-50\% of value added in the export volume of OECD countries is generated abroad. However, in the developing world these are traditionally China, India as large economies, and small countries, from Asian Tigers Group. Among developed countries, the largest EU economies (Germany, the UK and
Italy), as well as the USA, have demonstrated a high level of value added in their gross exports, with value-added services accounting for 40-50\% on average. [12] At the same time, we are talking about GVC in the services sector, where developed countries are the leaders.

International organizations were looking for a methodology for detailed analysis of geo-economic interrelationships taking place in the world economy and the possibility of regulating the reproduction process. It is needed for determining the participation of countries in the GVC.[6] The TiVA methodology developed by the OECD has many advantages as well as disadvantages. The main drawback is that during the current COVID pandemic crisis - 19 it is not effective, the current global crisis is unique, as in terms of its scale the crises of 1998 or 2008 and 2009 prevail. As the shutdown of regional production, especially in the countries of the "Global West", has led to an average decline of $10 \%$ in GDP dynamics until October 2020 and $7 \%$ from October 2020. With the expectation of a second wave, the situation will worsen, as unlike the first wave of the pandemic, the second wave will start with negative dynamics. While in China the same figures are $+1 \%$ and $+1.9 \%$. [12] This combination of circumstances will certainly have an impact on the management concept and delegation of authority within GVC.

From the perspective of the modernization concept, there is a problem in studying processes, where firms do not have sufficient assets and cannot manage the chain. In this case, they are subordinate. They then carry out international activities within the value-added system and ensure the transition from lower-value-added to higher-value-added products and thus increase the benefits of participating in GVC [2]. To this end, three main forms of modernization are distinguished: product modernization (improving product quality or design); process modernization (in terms of scale and speed, efficiency and productivity); functional 
modernization (acquiring new functions to increase the value added of activities in the chain) [4].

In the case of GVC, producer-oriented, capital-intensive and technology-driven management is a key productive activity. In the case of GVC, which is customer-oriented, we are talking directly about labour-intensive products and labour-intensive production (clothing, footwear and agrifood products). We could include members in this network who have exceptional advantages in their geographical location and benefit from transit potential. Although it can be said that of the total value added, this may not be the main factor if it is not in the geopolitical interests of the main GVC member countries.[14]

As a result, the activities, relationship forms, functional changes, distribution of values and, finally, forms of chain management on a global scale cannot be considered separately from the set of elements that form national trajectories and the public policies of the countries involved in the chain.

Based on the critical attitude towards state centrism [8], GVC's approach has prioritized an analysis of modernization and governance based on local-global design that ignores the complex and clearly defined set of elements related to the role of the state, social organizations and institutions within specific national trajectories.

The research developed under the GVC approach has mainly focused on sector-specific spatial analysis of local clusters included in global networks and mainly managed externally. Researches, related to cluster theories and GVC aimed at assessing cooperation between agglomerated firms in some developing countries regions such as East Asia and Latin America. From the point of view of some scientists, this approach may in fact stimulate modernization and inclusion in global chains [1] Archibugi and Pietrobelli 2003; [7] Giuliani et al. 2005; [9] Humphrey and Schmitz 2002; [13, 15] Pietrobelli and Rabellotti 2004; [10,11] Kaplinsky, R. (2000); [3] Chaminade and Vang 2008). By focusing on this research on the role of firms and their local clustering, and ignoring elements of the development of national economies, we cannot properly explain how particular macro-regions and countries may have been affected by specific chains. It also makes it difficult to explain how chains affect the various processes taking place in national economies. These problems cannot be solved, if the local bottom-up analysis of a chain is replaced by a bottom-up analysis of the activities of the leading firms, which are in fact the controlling and distributing entities. These actors will regulate different types of relationships and give some degree of autonomy to suppliers in developing countries in the context of different macro-regional and national scenarios. This approach does not allow analysis of the elements that form the national development trajectories of a country and the relationship of these elements with GVC, as it excludes analysis of the relationship between local production clusters and global value chains. [5] For this reason, even when countries are included in commodity chains [15], it is difficult to identify and assess the implications and results of the embedded national system in GVC. This entails considering how certain historical socio-economic and political structures and dynamics determine how global value chains penetrate and develop in this space, and how they affect the economic and institutional system of GVC entities.
Taking into account national trajectories and characteristics of socio-economic and political structures and their dynamics means analyzing not only the activities of firms, but also the state. In a certain sense, the issue of global reproduction involves integration factors that have several other qualities different from those that we are used to considering within the existing integration associations. These factors are related to the specifics of the actors involved, which are expressed in terms of different shares of capital, labour and political influence.

\section{METHODOLOGY}

The TiVA methodology covers only 64 countries, which does not allow for a detailed analysis of the degree of participation in GVC for many countries, including Azerbaijan. On this basis, an attempt was made to conduct an analysis based on a survey of the industry specifics of value creation.[19]

When we talked about the methodology for determining a country's role in GVC, we meant a tool to analyse international trade flows based on TiVA value added. This method is based on the creation of global Cost-Emission tables when initially combining national Cost-Emission tables, which take into account bilateral trade flows. The proposed TiVA model from the OECD-WTO was based on the "Costs-Out-Out" model developed by Vasily Leontiev.

In our study, we have shown the direct impact of a particular country's value added to the rest of the world (64 countries), and vice versa. At the same time, we did not specifically identify any particular industry. The indicators analysed, the origin of value added in gross exports (OVAGE), is an estimate of the gross exports of goods and services exported by industry I in country $\mathrm{C}$, broken down by value added from industry $\mathrm{J}$ in the source country/region $\mathrm{S}$.

In other words, it shows how the value of a country's gross exports of intermediate and final products is an accumulation of value created by many industries in many countries.

In calculating the origin of value added in final demand (OVAFD), estimates of final demand in country $\mathrm{C}$ for industry I in the final goods and services are broken down by the value added from industry $\mathrm{J}$ in source country $\mathrm{S}$.

In other words, it shows how the value of the final goods and services consumed in a country is an accumulation of value created by many industries in many countries.

Gross exports by origin of value added and final destination (GEOVA\&FD) is an estimate of gross exports by industry $\mathrm{I}$ in country $\mathrm{C}$, broken down by value added from source country/region $\mathrm{S}$ and by final demand from destination country/region P. In other words, it shows how the value of goods and services consumed in country I is accumulated by many industries in many countries.

The estimates are presented for country C, industry I, end goods and services exports (FD_EXGRFNL_VA), intermediate goods and services exports (FD_ EXGRINT_VA) and total exports (FD_EXGR_VA) and can show whose end demand stimulates the country's export activities.

These indicators can also show how the value added from source countries can rely on the export activities of industry $\mathrm{I}$ in country $\mathrm{C}$ to achieve the final demand in partner country 
P. However, it should be borne in mind that the same value added from source countries can be present in the gross exports of more than one exporting country $\mathrm{C}$ (as embodied value added from upstream production can cross national borders many times). These estimates should therefore be considered from the perspective of the $\mathrm{C}$ exporting country as a whole. In calculating the indicator of origin of value added in gross imports (OVAGI), estimates of gross imports by country $\mathrm{C}$ of goods and services from industry $\mathrm{I}$ in the partner country/region $\mathrm{P}$ by value added produced in origin country $\mathrm{C}$ are presented. Using the TiVA methodology, we investigated the degree of participation of some countries that have some indication to some extent in relation to Azerbaijan. The main feature was the high share of foreign trade relations. These are the countries of the former socialist camp (Czech Republic, Slovakia, Hungary, Romania, Poland), the postSoviet countries that are currently members of the EU (Baltic countries), Russia and Kazakhstan as CIS countries. In addition, the analysis includes such countries as Turkey and Italy, which are the largest partners in foreign trade turnover among developed countries. Based on multiple regression, we have identified which factors influence the increase in value added in the studied sectors of the economy of Azerbaijan. An analysis of the participation of trading partner countries allowed us to identify the possible degree of Azerbaijan's participation in GVC. Direct analysis of the value added in Azerbaijan shows a high proportion of the mining industry and, therefore, a low proportion of the manufacturing industry. (Figure 1)

In addition, as can be seen on the graph, the upstream industry is directly included by GVC, as the trend clearly reminds us of the volatility in the global oil market in times of global crisis. Whereas the manufacturing industry has a stable trend.

Figure 2. represents a graph showing the structure of intermediate consumption in Azerbaijan's industries. Here we can see how the manufacturing industry consumes a large proportion of raw materials, energy, spare parts, etc. for its products. This factor also indicates that imported products, which value added is higher than that created in Azerbaijan, participate in the creation of value added in the manufacturing industry.

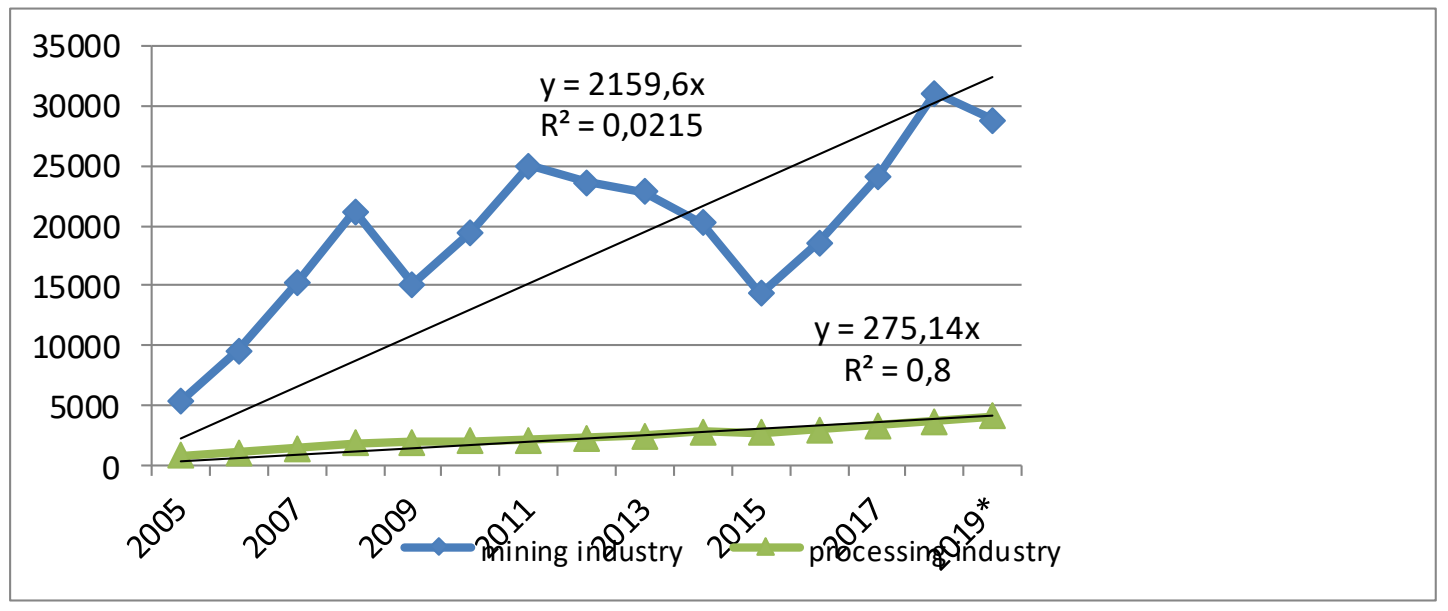

Fig.1. Value Added in Azerbaijan's industrial sectors

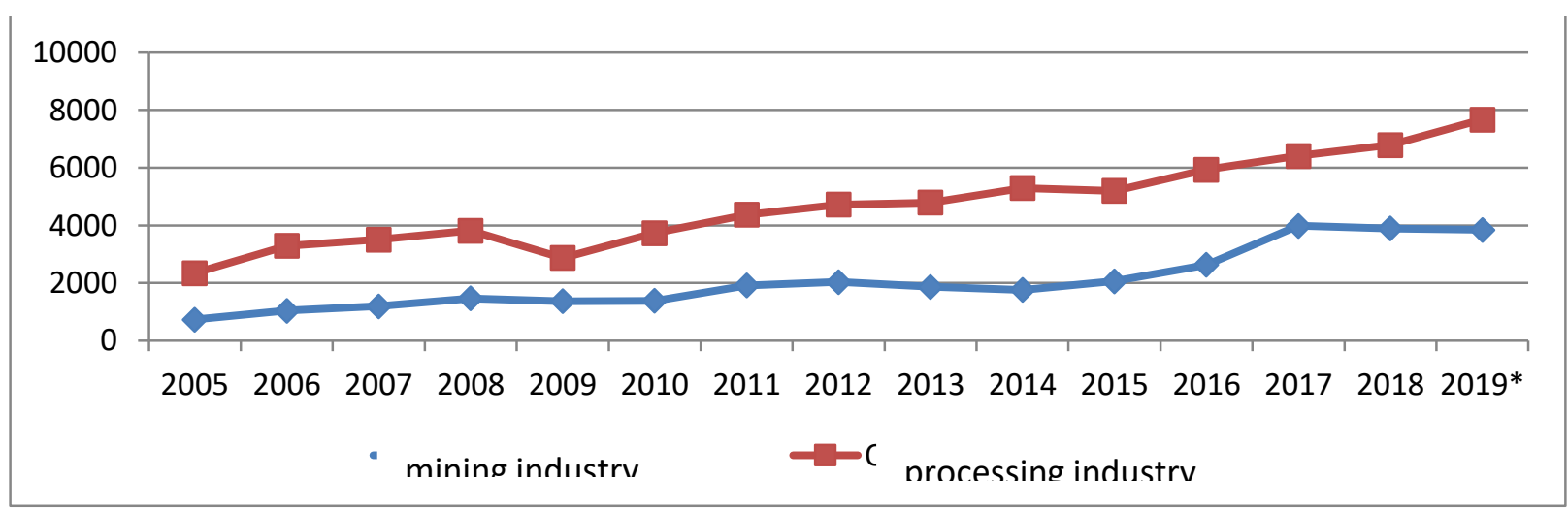

Fig.2. Intermediate consumption in Azerbaijan's industrial sectors

The production potential and subsequent replication process is directly linked to foreign trade activities, as we have already noticed the production of manufacturing products is somehow linked to the import of components of the final product. In our analysis of value added and intermediate consumption charts, we found that the largest intermediate consumption is in manufacturing with the lowest value added compared to mining. For example, the 
share of intermediate consumption in manufacturing output is more than $67 \%$, while in production it is about $10 \%$ and value added is $10.6 \%$ and $86.3 \%$ respectively. The high share of intermediate consumption is explained by the fact that Azerbaijan's trading partners, being mostly net importers of energy resources, are forced to increase the value of their products in parallel with the increase in world oil and gas prices, which leads them to a high level of energy intensity.

An important point in the country's foreign trade turnover is the participation of value added in exports, as this part of the value will directly affect the servicing of imports as well as import substitution policy. On this basis, we have calculated, for further analysis, the coefficients of import coverage by exports, which shows how much the country's exports exceed its imports.

If the import cover ratio for exports is higher than 1 , then exports cover the import. Calculations show that for the food industry, exports do not cover imports and vice versa, the import coverage factor for exports is higher than 1 and even closer to 1 in many cases. For chemical products, the import coverage factor for exports is higher than 1 until 2015 and therefore the import coverage factor for exports was lower than 1 . The situation has changed exactly to the opposite after
2015. The calculations give us the right to conclude that the chemical industry has enormous potential and the opportunity to enter into global value chains in this area, regardless of the depth of processing. From the perspective of the food industry, there are problems, above all, of an institutional nature. Since the food industry and related sectors of agriculture have the largest number of small and mediumsized enterprises. For a more detailed analysis, we have constructed a multiple regression equation for all the indicators that we analyzed. In addition, financial indicator M2 was included in this model in order to see how monetary policy affects the value added to the country's GDP.

\section{RESUlTS AND DISCUSSION}

The calculations have resulted in a multiple regression equation:

$\mathrm{VAGDP}=0.000255-0.000605 \mathrm{X}_{1}+0.04034 \mathrm{X}_{2}-$ $0.05272 \mathrm{X}_{3}-0.0289 \mathrm{X}_{4}+0.1064 \mathrm{X}_{5}-1.0546 \mathrm{X}_{6}+0.5415 \mathrm{X}_{7}$.

TABLE I. INPUT DATA For CONSTRUCTION OF MULTIPLE REGRESSION EQUATION

\begin{tabular}{|c|c|c|c|c|c|c|c|c|}
\hline \multirow[t]{2}{*}{ Year } & VAGDP & PII & M2 & IC & VAMI & GO & E/I FI & E/I Chem \\
\hline & $Y$ & $X 1$ & $X 2$ & $X 3$ & $X 4$ & $X 5$ & $X 6$ & $X 7$ \\
\hline 2005 & 6,5 & 163 & 133 & 74,3 & 13,1 & 32,5 & 0,8 & 5,16 \\
\hline 2006 & 5,8 & 187 & 136,7 & 75,3 & 8,4 & 21,9 & 0,6 & 5,65 \\
\hline 2007 & 5 & 200 & 127,2 & 71,3 & 8 & 19,2 & 0,6 & 4,54 \\
\hline 2008 & 4,7 & 184 & 126,9 & 66,9 & 11,2 & 21,5 & 0,5 & 3,64 \\
\hline 2009 & 5,5 & 202 & 129,7 & 59,3 & 9,2 & 20,5 & 0,6 & 2,68 \\
\hline 2010 & 4,7 & 216 & 132,9 & 65 & 7,4 & 18,4 & 0,5 & 3,04 \\
\hline 2011 & 4 & 228 & 131,3 & 67,8 & 8,6 & 20,3 & 0,6 & 2,57 \\
\hline 2012 & 4,2 & 241 & 141,2 & 67 & 9,3 & 21,4 & 0,7 & 1,75 \\
\hline 2013 & 4,2 & 246 & 151,1 & 66,1 & 11,4 & 25,1 & 0,6 & 1,74 \\
\hline 2014 & 4,7 & 263 & 124,8 & 65,6 & 15,2 & 29,9 & 0,6 & 2,23 \\
\hline 2015 & 5 & 266 & 146,9 & 65,7 & 13,2 & 27,5 & 0,7 & 1,34 \\
\hline 2016 & 4,9 & 261 & 145,9 & 66,7 & 11,7 & 24,3 & 0,4 & 0,93 \\
\hline 2017 & 4,7 & 281 & 153,4 & 66 & 10,4 & 21,9 & 0,5 & 0,67 \\
\hline 2018 & 4,6 & 314 & 157,5 & 64,7 & 12,2 & 25 & 0,6 & 0,68 \\
\hline & & & & f paired & coefficie & & & \\
\hline - & $\mathrm{y}$ & $\mathrm{x}_{1}$ & $\mathrm{x}_{2}$ & $\mathrm{x}_{3}$ & $\mathrm{x}_{4}$ & $\mathrm{X}_{5}$ & $\mathrm{x}_{6}$ & $\mathrm{x}_{7}$ \\
\hline y & 1 & 0.7502 & 0.8988 & 0.9512 & 0.8307 & 0.9063 & 0.9056 & 0.6669 \\
\hline $\mathrm{x}_{1}$ & 0.7502 & 1 & 0.9421 & 0.847 & 0.8543 & 0.8302 & 0.7665 & 0.1085 \\
\hline $\mathrm{x}_{2}$ & 0.8988 & 0.9421 & 1 & 0.9592 & 0.8626 & 0.894 & 0.8811 & 0.3767 \\
\hline $\mathrm{x}_{3}$ & 0.9512 & 0.847 & 0.9592 & 1 & 0.8443 & 0.9056 & 0.9191 & 0.6005 \\
\hline $\mathrm{x}_{4}$ & 0.8307 & 0.8543 & 0.8626 & 0.8443 & 1 & 0.9742 & 0.8335 & 0.3014 \\
\hline $\mathrm{X}_{5}$ & 0.9063 & 0.8302 & 0.894 & 0.9056 & 0.9742 & 1 & 0.9112 & 0.4473 \\
\hline $\mathrm{x}_{6}$ & 0.9056 & 0.7665 & 0.8811 & 0.9191 & 0.8335 & 0.9112 & 1 & 0.5786 \\
\hline $\mathrm{x}_{7}$ & 0.6669 & 0.1085 & 0.3767 & 0.6005 & 0.3014 & 0.4473 & 0.5786 & 1 \\
\hline
\end{tabular}

VAGDP - Value Added to GDP, PII - Process Industries Index, IC - Intermediate consumption, VAMI - value added to the manufacturing industry, GO - Gross output, E/I FI and E/I Chem - import export coverage ratios 
Economic interpretation of the model parameters is possible: increase in manufacturing index by 1 unit of change leads to decrease in DS of GDP (Y) by 0.000605 units of change on average; increase in M2 by 1 unit of change leads to increase in $\mathrm{Y}$ by 0.0403 units of change on average; increase in intermediate consumption by 1 unit of change leads to decrease in $\mathrm{Y}$ by 0.0527 units of change on average; increase in DS of manufacturing by 1 unit of change. leads to an increase in $\mathrm{Y}$ on average by 0.0289 units of change; an increase in the gross manufacturing output by 1 unit of change leads to an increase in $\mathrm{Y}$ on average by 0.106 units of change; an increase in the food industry export cover factor by 1 unit of change leads to a decrease in Y on average by 1.055 units of change; an increase in the chemical industry export cover factor by 1 unit of change leads to an increase in $\mathrm{Y}$ on average by 0.542 units of change. Based on the maximum coefficient $\beta 2=1.087$, we conclude that the greatest influence on the result of $\mathrm{Y}$ is produced by the monetary policy factor.

Thus, for sustainable growth, it is necessary to develop the production of goods and services with a high share of added value. As we can see from the model built, an increase in the coefficient of import export coverage in the food industry by 1 unit of change may lead to a decrease in DS in GDP by an average of 1,055 units of change. The explanation for this result may be institutional factors and the industry's high dependence on imported ingredients, but with a less complex technological chain, this industry may act as a kind of 'integrator' of domestic value chains. This is possible due to the industry's use of predominantly domestic raw materials, which will achieve high value-added along the entire production chain.

The following analysis was based on calculations of indicators such as "Origin of value added in gross exports" (OVAGE), "Origin of value added in final demand" (OVAFD), "Gross exports by origin of value added and final destination" (GEOVA\&FD) and "Origin of value added in gross imports" (OVAGI). The four dimensions of TiVA link the imports of country $\mathrm{C}$ to the value added from source country $\mathrm{S}$ embodied in the exports of industry $\mathrm{I}$ in the exporting country $\mathrm{P}$ - thus revealing how the value of a country's gross imports of intermediate and final products from a particular partner is an accumulation of value generated by many countries. $[17,18]$

Based on the analysis, countries with OVAGE below $60 \%$ have the highest involvement in long GVC chains. This means that the value added of these countries depends on the other chain participants who have the highest share of value added in exports. These are mainly the EU CEE member countries. An important factor is that for these countries, the OVAGE indicator has decreased, albeit slightly. This means that they are systematically included in the GVC (mainly within the EU) and that they are final collectors, which results in lower value added in their exports. Russia and Kazakhstan, as producers and exporters of resources, have a high value added of more than $90 \%$. Turkey, by its production structure, creates a closed production cycle with a high level of exports, which leads to an increase in value added of more than $80 \%$. For OVAFD, we can conclude that the higher the OVAFD, the more imported components in the end product exports. A reduction in this indicator may be due to an import substitution policy. The analysis identifies the most favourable situation for the CEE and Baltic countries, which, along with inclusion in the long GVC chains, simultaneously produce products for domestic consumption with high value added.

The analysis of GEOVA\&FD and OVAGI indicators showed that the contribution of value added for the CEE and Baltic countries to the final consumption and imports of partner countries is rather low. For example, these figures for Belgium are $77 \%$ and $0.67 \%$, while for the European countries analysed they are approximately $1 \%$ and $0.14 \%$. The results obtained are fully consistent with our findings regarding GVC management and the division of powers within the network, as well as the country's contribution by GEOVA\&FD and OVAGI indicators.

\section{CONCLUSIONS}

Our research shows that the specifics of Azerbaijan's value added corresponds mainly to the countries, such as Kazakhstan and Russia. The high level of value added in energy resources allows expanded reproduction in the national economy. However, the decline in the global oil price limits this process and consequently reduces the level of participation in GVC, and also affects the decline in revenues from other goods and services, that are supplied to importer markets. The decline in the oil price also has a negative impact on the economies of countries that are also dependent on oil exports and therefore will not only be unable to develop other industries, but will also be unable to purchase products from other countries, even if they are in a network. On this basis, there is the challenge of finding new opportunities at a time when the global economy is undergoing transformation. The policy pursued by the Government of Azerbaijan is to develop the non-oil sector on the basis of the Strategic Road Map. It may reveal alternative sources of exports through the development of the chemical industry, agriculture and services. But in order to identify these alternatives, it is necessary to assess the aggregated value chains that unite enterprises into a single technological process for the production of final high value-added products.

\section{REFERENCES}

[1] Archibugi and Pietrobelli. The Globalisation of Technology and its Implications for Developing Countries: Windows of Opportunity or Further Burden? Technological Forecasting and Social Change, 2003, 70(9):861-883. DOI: 10.1016/S0040-1625(02)00409-2.

[2] J. Bair, and G. Gereffi, "Upgrading, uneven development, and jobs in the North American apparel industry". Global Networks 3, 2, 2003, pp. 143-169.

[3] C. Chaminade, J. Vang, Globalisation of Knowledge Production and Regional Innovation Policy: Supporting Specialized Hubs in the Bangalore Software Industry,2008, no 20.

[4] G. Gereffi, G. "International trade and industrial upgrading in the apparel commodity chain", Journal of International Economics, 1999, vol. 48 , pp.37-70.

[5] G. Gereffi, "Shifting governance structures in global commodity chains, with special reference to the Internet", American Behavioral Scientist, 2001, vol. 44, pp.1616-37.

[6] G. Gereffi, R., "Garcia-Johnson and E. Sasser. The NGO-industrial complex", Foreign Policy, 2001, vol. 125, pp. 56-65.

[7] E. Giuliani, C. Pietrobelli, R. Rabellotti, "Upgrading in Global Value Chains: Lessons from Latin American Clusters, World Development, 2005, 33, pp. 549-573/DOI: 10.1016/j.worlddev.2005.01.002.

[8] J. Glassman, The Geo-political Economy of Global Production Networks, 2011, DOI: https://doi.org/10.1111/j.17498198.2011.00416.x

[9] J. Humphrey, H. Schmitz, "How Does Insertion in Global Value Chains Affect Upgrading in Industrial Clusters?", February 2002 Regional Studies, vol. 36(9), pp.1017-1027 
[10] R. Kaplinsky, Globalisation, industrialization, and sustainable growth: the pursuit of the nth rent, Discussion Paper 365, Institute for Development Studies, University of Sussex, 1998.

[11] R. Kaplinsky, Spreading the gains from globalization: what can be learned from value chain analysis, Working Paper 110, Institute for Development Studies, University of Sussex, 2000.

[12] P. Kowalski, J.L. Gonzalez, A. Ragoussis, Ugarte Participation of Developing Countries in Global Value Chains, Implications for trade and traderelated policies OECD, 2015.

[13] A. Morrison, C. Pietrobelli, R. Rabellotti, Global Value Chains and Technological Capabilities: A Framework to Study Industrial Innovation in Developing Countries, 2008.

[14] F. Palpacuer, A. Parisotto, "Global production and local jobs: can global enterprise networks be used as levers for local development?", Global Networks, 2003, vol. 3, pp.97-120.

[15] R. Rabellotti, "Recovery of a Mexican cluster: devaluation bonanza or collective efficiency?", World Development,1999, vol. 27, pp. 157185.

[16] H. Schmitz, and K. Nadvi, "Clustering and industrialization: introduction", World Development, 1999, vol. 27, pp.1503-14.

[17] Trade in Value Added (TiVA): Origin of value added in gross imports, URL:

https://stats.oecd.org/Index.aspx?DataSetCode=TIVA 2018 C5/(acce ssed 08.11.2020)

[18] Guide to OECD's Trade in Value Added (TiVA) Indicators, 2018 edition, URL: http://www.oecd.org/sti/ind/tiva/TiVA2018_Indicators_Guide.pdf/(ac cessed 08.11.2020).

[19] Trade in Value Added. URL: http://www.oecd.org/sti/ind/measuringtrade-in-value-added.htm/(accessed 08.11.2020).

[20] The state statistical committee of the Repudlic of Azerbaijan. URL: https://www.stat.gov.az/source/system nat accounts/(accessed 08.11.2020). 